\title{
Cost and Benefit Analysis: Two Scenarios in the Treatment of Worm Disease (Coccidiosis) as a Cause of Calf Death in the District of Mukomuko City, Mukomuko District, Bengkulu
}

\author{
Tri Guntoro \\ Epidemiology, DIC Lampung \\ Lampung, Indonesia \\ guntoros2_2005@yahoo.co.id
}

\author{
Elwaldrus Wera \\ Kupang State Agricultural Polytechnic \\ NTT, Indonesia \\ nanawaldi@yahoo.com
}

\author{
Ferro \\ Epidemiology, DIC Lampung \\ Lampung, Indonesia
}

\begin{abstract}
Losses due to parasitic infections, especially worms in livestock in Indonesia are very large. Helminthiasis is a disease in beef cattle which is common in traditional farms. This study aims to use a cost-benefit analysis for two scenarios in handling helminthiasis (coccidiosis), namely Program A (controlling worming with Albendazole and one type of antibiotic) and Program $B$ (controlling administering coccidiosis drug and two types of antibiotics). The activity began with the investigation of animal diseases in the city of Mukomuko, Kab. Mukomuko, Bengkulu in the activity obtained information that calves were not given worm medication 8.14 times the risk of helminthiasis that ended in death and worms found $\mathbf{4 0} \%$ Eimeria (Coccidiosis). The results of a cost-benefit analysis of helminthiasis with details of the first scenario (NPV: 191,682,324; BCR: 2.95; IRR: 169.08\%) and the second scenario (NPV: 1,018,538,931; BCR: 4 , 37; IRR: 241,62). From this value the two programs provide a positive net present value (NPV) but in the second scenario it is greater than the first and the return on investment is greater than the discount rate, while the benefit and cost ratio ( $\mathrm{B} / \mathrm{C}$ ratio) $>1$ for both scenarios but the second scenario has a ratio of 2 times greater than the first scenario. Taking into account the three criteria of benefit cost analysis, it can be said that the control of helminthiasis (coccidiosis) in the second scenario is better and more efficient than the first scenario.
\end{abstract}

Keywords- Benefit Cost Analysis, Pedet, Worming (coccidiosis)

\section{INTRODUCTION}

Cattle rearing systems in Muko-Muko are generally still carried out extensively and semi-intensively. Cattle rearing systems that are still classified as traditional as this are susceptible to infections from various diseases. This situation results in significant losses and affects the income of farmers. Losses due to disease infection include a decrease in production results due to stunted growth of livestock and increased costs that must be spent for the treatment of infected cattle (Subronto, 2007). Diseases that are often ignored by farmers are diseases caused by worm parasites. In terms of economic calculations, cattle disease caused by worm parasites results in very high losses for farmers. Worm infections in the digestive tract cause digestive disorders of cows and competition occurs in the absorption of food nutrients so that cow growth will be hampered (BPTP NTB, 2011). Especially if the worms are zoonotic, in addition to economic losses caused by their health is also threatened (Medicastore, 2011). Animal disease investigation in the city of Mukomuko, Kab. Mukomuko, Bengkulu in the activity obtained information calf $40 \%$ infected with coccidiosis (Susilo, 2019). The results of tests conducted by the Disease Investigation Center of parasitology laboratory are as follows: $40 \%$ (Eimeria), 5\% (Paramphistomum), 5\% (Ascaris), 5\% (Strongiloides), and 10\% (Trichostrongylus).

The most common health disorders especially in the preweaning calf are diarrhea (Wudu et al., 2008, Debnath et al., 1995, Azzizadeh et al., 2012, Wymann etal, 2006, Smith, 2009). Diarrhea which causes huge losses because it not only causes an increase in maintenance costs and mortality, but also reduces livestock productivity in the future. Diarrhea occurs due to an increase in the number of pathogenic bacteria, especially coliform in the small intestine, but there is a decrease in the population of bacteria Lactobacillus and Bifidobacteria (Krehbiel et al., 2003; Ouwehand et al., 2002). Health problems in pre-weaning calf in addition to diarrhea are umbilical cord infections, bloat / bloating, intestinal worms, enteritis and pneumonia. The mortality rate of pre-weaning calves in community farms can reach $68 \%$ in India (Tiwari et al., 2007), 35\% in Zimbabwe (French et al., $2001), 10 \%$ to $19 \%$ in traditional and intensive farms in Mali (Wymann et al., 2006), and 25\% in Tanzania (Kivaria et al., 2006). Lower calf mortality rates occur in European countries, varying from $4 \%$ in Sweden (Svensson et al., 2009) and $7.8 \%$ in Norway (Gulliksen et al., 2009). 
Rahayu's research results, 2014 showed that the calf mortality rate in category people's livestock farms was high, amounting to 48 out of 245 calves in the study sample (19, $59 \%)$. Disease events found in farm companies include: diarrhea (61.73\%), pneumonia (25.61\%), umbilical cord infection $(4.22 \%)$, post-cut horn infection $(4.22 \%)$, and limp (4) , 22\%). The mortality of Balinese calf kept in oil palm plantations is quite high reaching $30 \%$ (Toelihere, 2002). The highest incidence of calf death is a newborn calf, not getting the attention of its parent and an unsupported management system. In addition, most calf deaths in Bali cattle are thought to be caused in the dry season when the quality and quantity of feed sources is low, which causes low milk production of less than 1.5 liters per day (Belli, 2002). Calf that eats grass under oil palm plantations is susceptible to endoparasites and other protozoa that cause bloody diarrhea, Eimeria sp. In general, coccidiosis treatment therapies are considered ineffective due to mucosal lesions in the intestine (Fitzgerald, 1980), so tissue damage due to coccidiosis will inevitably lead to the severity of diarrhea disease. Economic losses due to calf mortality are quite high, calves are the investment and the main result of the integration of cattle and oil palm plantations.

Benefit cost analysis is often used in handling animal diseases, this analysis is used to find the value and comparison of costs and benefits of an activity and convert it to economic value to see which gives the best benefits by using the most efficient resources (Turnbull et al., 1998; Otte and Chilonda. 2002; Gilfoyle, 2006; Mongoh et al., 2008; APHIS, 2009).

This study aims to use a cost-benefit analysis for two scenarios in handling helminthiasis (coccidiosis), namely Program A (controlling worming with Albendazole and one type of antibiotic) and Program B (controlling administering coccidiosis drugs and two types of antibiotics). The results of this study are expected to provide benefits to the government/ policy makers in determining the most appropriate control program to be implemented based on the scale of priorities and the most beneficial form of strategy.

\section{MATERIALS DAN METHODS}

\section{A. Determination of Sample and Data Collection}

Respondent data collection was carried out in Muko Muko District, Bengkulu Province, which was preceded by an investigation by the DIC Lampung team, from the results of the FGD and secondary data collection, the data for this study were only in the Muko Muko sub-district because of higher death compared to other regions.

The sampling method is purposive random sampling by modifying the technique carried out by Dhand et al. (2005) and Ugwu (2009). The data used in this study are primary data and secondary data. Primary data are input and output of helminthiasis activities in calves obtained from interviews with cattle farmers affected by helminthiasis. Secondary data include data on livestock population, investigation costs, laboratory testing costs, treatment of helminthiasis, cases of helminthiasis, calf cattle prices and livestock transportation as well as other data related to this study. Secondary data were collected from related agencies or agencies such as the Livestock Service Office of Muko Muko Bengkulu District, type A laboratories and veterinary medical staff.

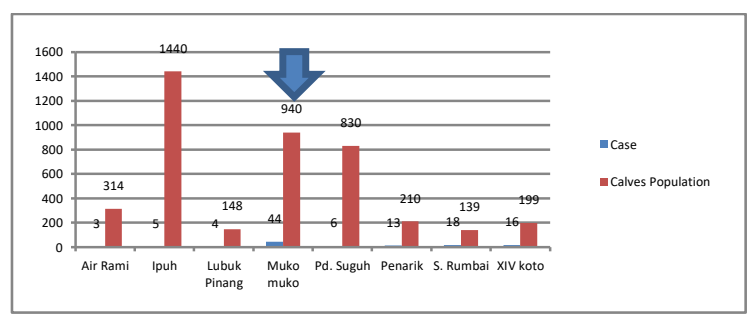

Fig. 1. Distribution of Bali calf mortality compared to the population in each district in 2016 - 2018 (Susilo, J 2019)

\section{B. Data analysis}

Benefit cost analysis is carried out with the following stages: (1) determination of current gross profit in the presence of worm disease (coccidiosis), (2) preparation of variables that affect the gross margin with a disease control program, (3) determination variable costs needed to carry out disease control programs, (4) determination of the length of time of the benefits and costs and the year that the benefits are fully felt, (5) compilation of a list of initial costs (investment costs) that will be needed and specify when these costs are included, (6) determining the size of the area to be analyzed, for example the number of animals to be included in the program, (7) making three-year cash flows for both scenarios, (8) determining the applicable discount, and (9) comparing control alternatives using criteria net present value (NPV), benefit / cost ratio (benefit / cost ratio, BCR) and internal rate of return (IRR). Cost benefit data are analyzed for the scope of the veterinary economy and control strategies (Kusbianto, 2012).

\section{RESULTS AND DISCUSSION}

The implementation of environmental sanitation management is an important factor to minimize gastrointestinal parasitic infestations (Taylor et al. 2007; Zajac, 2012). Provision of worm medicine that is routinely carried out is a practice of animal health management that is needed calves and broodstock. Stefaniak (2004) argues that the period of neonatal diarrhea is one of the main reasons for morbidity and calf death. It is estimated that the acute diarrhea period causes $75 \%$ of calf deaths at the age of three weeks. Death is most often caused by enterotoxigenic strains of Escherichia coli and Rotavirus, which are followed by complex infections. 
In this study two scenarios are presented in the handling of helminthiasis (coccidiosis) events that have an impact on mortality in calves in the district of Muko Muko, Muko Muko Regency, Bengkulu Province:

1. Calves are treated with worm medicine (albendazole group) and sulfa group antibiotics (scenario 1);

2. Calves are given treatment with special worm medicine for eimeria (coccidia), antibiotics (sulfa and penicillin) added with additional milk (scenario 2 )

From the results of testing in the Laboratory of Parasitology, Disease Investigation Center $40 \%$ found eimeria (coccidiosis), therefore this research is more focused on the incidence of coccidiosis. Analysis of the cost of the benefits of coccidiosis control in cattle is done by making a cash flow calculation for a period of 3 years and using the input data contained in these tables. From the cash flow data, three control parameters can be calculated, namely the NPV value, the B / C ratio and the IRR (in Tables 2 and 4) Based on the NPV obtained, controlling coccidiosis through a treatment program with Kalzoril (coccidiosis drugs) and antibiotics (sulfa and penicillin) provide greater income when compared to other programs. This can be understood because the number of livestock (calves) that can be saved is more due to the death of calves in Muko Muko from 2016 to 2018 (57\%) (Susilo, 2019).

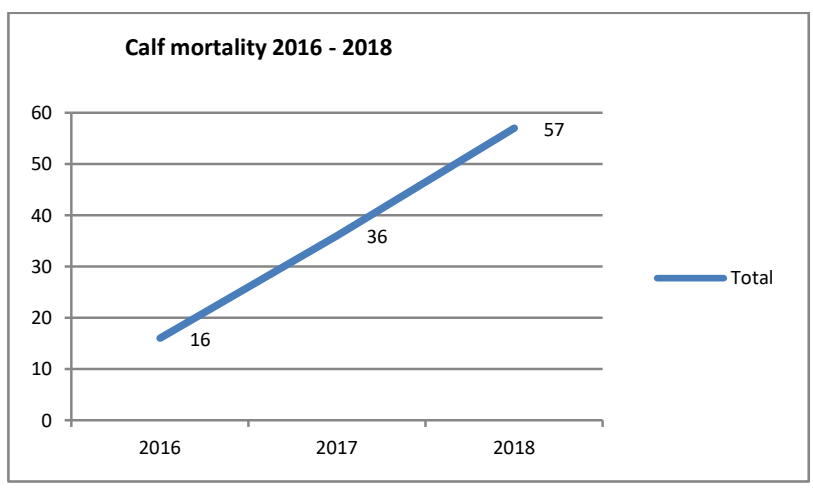

Fig. 2 Death patterns of Balinese cattle calf in the District of Muko Muko in 2016 - 2018 (Susilo, J 2019)

Government efforts in this disease control program will be more precise and bring benefits with the second scenario, namely treatment with the good drugs in accordance with those found in accordance with the results of previous investigations $40 \%$ incidence of Coccidiosis in calves in Muko Muko sub-district, Muko Muko district, Bengkulu Province. The main problem in the case of calf diarrhea and also in adult livestock is dehydration caused by loss of fluid in the body and decreased milk intake from the mother. Long-term and persistent diarrhea can cause fatal homeostasis disorders (Sobiech, P 2007). The addition of milk substitutes is very helpful in dehydration conditions so that the calf can be saved. Based on information from the veterinary medical district Muko Muko after proper treatment, almost 100 percent recovered and calves can develop into adulthood. So that the second scenario is more efficient and can save calves born in oil palm plantations.

\section{IV.CONCLUSIONS}

- Appropriate treatment according to the type of worm eggs found will be more useful;

- Supplementation of extra milk will be very helpful when the cow is dehydrated because of lack of good milk intake from the mother;

- With limited resources, we can choose the second scenario to reduce calf mortality in cattle with traditional rearing and or rearing of oil cows.

\section{LIMITATION}

The cure rate is based on judgment (interview) not literature.

\section{ACKNOWLEDGEMENTS}

The author's appreciation and gratitude goes to the Muko Muko District Animal Husbandry Department who is willing to serve as a place for this research. And also the Lampung Veterinary Center Investigation Team for the information and preliminary study.

\section{REFERENCES}

[1] Azizzadeh, Mohammad, Hadi Fazeli Shooroki, Ali Sha $\square$ ee Kamalabadi, Mark A. Stevenson. 2012. Factors Affecting Calf Mortality in Iranian Holstein Dairy Herds. Preventive Veterinary Medicine. 104 (2012) : 335-340.

[2][APHIS] Animal and Plant Health Inspection Service. 2009. Benefit-Cost Analysis of the National Animal identification System. United States Department of Agriculture.

[3] Belli, H. L. L. 2002. Supplementaion to improve the performance of grazing Bali cows (Biboss banteng Wagner). PhD Thesis. University of Gottingen, Goettingen.

[4] Chilonda P, Otte MJ. 2006. Indicators to monitor trends in livestock production at national, regional and international levels. Livestock Res Rur Dev 18(8): 1-8.

[5] Dhand NK, Gumber S, Singh BB, Aradhana, Bal MS, Kumar H, Sharma DR, Singh J,Sandhu KS. 2005. A study on the epidemiology of brucellosis in Punjab (India)using Survey Toolbox. Rev Sci Tech Off IntEpiz. 24(3): 879-885.

[6] Debnath, N.C., M.J.F.A. Taimur", A.K. \&ha”, M. Ersaduzaman", M. Helaluddin”, M.L. Rahman”, D.K. Royb, M.A. Islam. 1995. A retrospective study of calf losses on the central dairy cattle breeding station in Bangladesh Preventive Veterinary Medicine 24 (1995) 4353

[7] Gatot Prabantoro , Paper "Measuring the Economic Feasibility of Management Information System Projects, Using the Method' Cost \& Benefits Analysis and Its Applications Dengan MS EXCEL 2000. STIE Indonesia

[8] Krehbiel, C.R. , S.R. Rust, G. Zhang, and S.E. Gilliland. 2003. Bacterial direct fed microbials in ruminants diet: Performance response and mode of action. J. Dairy Sci. 81 (E. Suppl. 2): E120-132 
[9] Medicastore. 2011. Toxocariasis. Infections and Infectious Diseases. Http://medicastore.com/penyakit/220/Toksokariasis.html (05-022016)

[10] Mongoh MN, Hearne R, Khaitsa ML. 2008. Private and public economic incentives for the control of animal diseases: the case of anthrax in livestock. Transbound Emerg Dis 55(8):319-28.

[11] Otte MJ, Chilonda P. 2002. Animal Health Economics: An Introduction. Livestock Information, Sector Analysis and Policy Branch, Animal Production and Health Division (AGA). Food Agriculture Organization (FAO). Rome Italy

[12] Sayuti, Linda. (2007). Liver Worm Infection (Fasciola sp.) In Bali cattle di Kab Karangasem. Bogor: Institut Pertanian Bogor

[13] Subronto. 2008. The Science of Livestock Disease. Yogyakarta: Gadjah Mada University Press. 58-
[14] Suweta, I.G.P. 1985. Penyuluhan Penggulangan Penyakit Parasiterpada Ternak di Kabupaten Gianyar. Laporan Penelitian.PusatPengabdian Pada Masyarakat. Universitas Udayana, Denpasar.

[15] Taylor, M.A., Coop, R.L., Wall, R.L. 2007. Veterinary parasitology. Oxford (UK): Blackwell Publishing.

[16] Toliehere, M.R. 2002. Increasing the success rate and adoption of artificial insemination for genetic improvement of Bali cattle. Proc. ACIAR Workshop on Strategies to Improve Bali Cattle in Eastern Indonesia, Denpasar, Bali, February 4-7, 2002. Page 48-53.

[17] Ugwu DS. 2009. Socio-Economic Impact of HIV/ AIDS on Farm Women in Nigeria: Evidence from Enugu State. World App Sci J 6(12): 1617-1624.

[18] Zajac, A.M. 2012. Clinical veterinary parasitology. 8th Ed. Iowa (US): Blackwell Publishing.

\section{APPENDICES}

TABLE 1. PARAMETERS IN THE FIRST SCENARIO

\begin{tabular}{|c|c|c|c|c|}
\hline Economic impact of Coccidiosis & & & & Unit \\
\hline morbidity rate & Ks & & $60.00 \%$ & \\
\hline mortality rate & $\mathrm{K}_{\mathrm{m}}$ & & $90.00 \%$ & \\
\hline number of dead animals & $\mathrm{n}_{\mathrm{m}}$ & & 684 & heads per year \\
\hline number of diseased animals & $\mathrm{n}_{\mathrm{s}}$ & & 456 & heads per year \\
\hline Vitamin & $\mathrm{V}_{\mathrm{a}}$ & & $5,000.00$ & per head \\
\hline calves sale price without Jembrana outbreak & $\mathrm{H}_{\mathrm{tw}}$ & & $2,000,000.00$ & per head \\
\hline Total direct loss & $\mathrm{K}_{\mathrm{I}}$ & & Rp 1,370,280,000.00 & per annum \\
\hline \multicolumn{5}{|l|}{ B. Indirect loss } \\
\hline \multicolumn{5}{|l|}{ B.1. Loss due to the quarantine of the area } \\
\hline \multicolumn{5}{|l|}{ B.1.1. Farmers } \\
\hline Percentage of price drop during outbreak & $\mathrm{P}_{\mathrm{ph}}$ & & $90 \%$ & \\
\hline Percentage of sold calves & $\mathrm{P}_{\mathrm{sj}}$ & & $10 \%$ & \\
\hline Loss for the inter-area (interdistrict) traders & $\mathbf{K}_{\mathrm{pd}}$ & $\mathbf{R p}$ & $20,900,000.00$ & per annum \\
\hline \multicolumn{5}{|l|}{ B.1.3. Livestock transportation business owners } \\
\hline Transportation cost for cattle out of Muko muko & $\mathrm{T}_{\mathrm{sl}}$ & $\mathrm{Rp}$ & $200,000.00$ & per head \\
\hline Loss for the transportation business & $\mathrm{K}_{\mathrm{tt}}$ & $\mathbf{R p}$ & $16,720,000.00$ & per annum \\
\hline Total loss due to the quarantine of the area & $\mathrm{K}_{\mathrm{pw}}$ & $\mathbf{R p}$ & $119,700,000.00$ & per annum \\
\hline \multicolumn{5}{|l|}{ B.2. Jembrana control costs } \\
\hline \multicolumn{5}{|l|}{ B.2.1. Investigation costs } \\
\hline Number of personnel & $\mathrm{n}_{\mathrm{i}}$ & & 4 & pax \\
\hline Daily rate & $\mathrm{L}_{\mathrm{i}}$ & $\mathrm{Rp}$ & $380,000.00$ & per person / day \\
\hline Accommodation & $\mathrm{B}_{\mathrm{a}}$ & $\mathrm{Rp}$ & $550,000.00$ & per room / day \\
\hline Accommodation unit & $\mathrm{n}_{\mathrm{a}}$ & & 2 & room \\
\hline accommodation days & $\mathrm{H}_{\mathrm{m}}$ & & 3 & day \\
\hline Laboratory costs & $\mathrm{B}_{1}$ & $\mathbf{R p}$ & $170,000.00$ & per package \\
\hline \multicolumn{5}{|l|}{ B.2.3 Albendazole + Antibiotic (One type) } \\
\hline Coverage & $\mathrm{C}_{\mathrm{v}}$ & & $100 \%$ & \\
\hline dosages & $\mathrm{n}_{\mathrm{va}}$ & & 760 & dosage \\
\hline
\end{tabular}




\begin{tabular}{|c|c|c|c|c|}
\hline Drug price & $\mathrm{H}_{\mathrm{va}}$ & $\mathrm{Rp}$ & $10,000.00$ & per dosage \\
\hline vaccination costs & $\mathbf{B}_{v}$ & $\mathbf{R p}$ & $22,800,000.00$ & per annum \\
\hline Coccidiosis control costs & $\mathbf{B}_{\mathrm{pj}}$ & $\mathbf{R p}$ & $36,100,000.00$ & per annum \\
\hline Coccidiosis total loss & $\mathbf{T}_{\mathrm{KJ}}$ & $\mathbf{R p}$ & $1,526,080,000.00$ & per annum \\
\hline
\end{tabular}

TABLE 2. CALCULATION OF THE FIRST SCENARIO COST AND BENEFIT ANALYSIS (WITH DISCOUNT RATE 5.00\%)

\begin{tabular}{|c|c|c|c|c|c|}
\hline \multirow[b]{2}{*}{ Item } & \multicolumn{4}{|c|}{ Year } & \multirow[b]{2}{*}{ Total } \\
\hline & 0 & 1 & 2 & 3 & \\
\hline \multicolumn{6}{|l|}{ Costs } \\
\hline \multicolumn{6}{|l|}{ Recurrent costs } \\
\hline Investigation costs & & $13,130,000$ & $13,130,000$ & $13,130,000$ & $39,390,000$ \\
\hline Laboratory costs & & 170,000 & 170,000 & 170,000 & 510,000 \\
\hline Albendazole + Antibiotic (One type) & & $22,800,000$ & $22,800,000$ & $22,800,000$ & $68,400,000$ \\
\hline \multicolumn{6}{|l|}{ Benefits } \\
\hline Losses of animals and treatments & & 0 & & $274,056,000$ & $274,056,000$ \\
\hline General economy & & 0 & $35,910,000$ & $23,940,000$ & $59,850,000$ \\
\hline Total benefits & 0 & 0 & $35,910,000$ & $297,996,000$ & $333,906,000$ \\
\hline Undiscounted benefits minus costs & $\mathbf{0}$ & $-36,100,000$ & $-190,000$ & $261,896,000$ & $225,606,000$ \\
\hline Discounted costs & $\mathbf{0}$ & $34,380,952$ & $32,743,764$ & $31,184,537$ & $98,309,254$ \\
\hline IRR & $169.08 \%$ & & & & \\
\hline
\end{tabular}

TABLE 3. PARAMETERS IN THE SECOND SCENARIO

\begin{tabular}{|c|c|c|c|c|}
\hline Economic impact of Coccidiosis & & & & Unit \\
\hline population & $\mathrm{N}$ & & 760.00 & heads \\
\hline morbidity rate & Ks & & $60.00 \%$ & \\
\hline number of dead animals & $\mathrm{n}_{\mathrm{m}}$ & & 684 & heads per year \\
\hline number of diseased animals & $\mathrm{n}_{\mathrm{s}}$ & & 456 & heads per year \\
\hline Vitamin & $\mathrm{V}_{\mathrm{a}}$ & & $5,000.00$ & per head \\
\hline calves sale price without Jembrana outbreak & $\mathrm{H}_{\mathrm{tw}}$ & & Rp $\quad 2,000,000.00$ & per head \\
\hline Total direct loss & $\mathrm{K}_{\mathrm{l}}$ & & Rp 1,370,280,000.00 & per annum \\
\hline \multicolumn{5}{|l|}{ B. Indirect loss } \\
\hline \multicolumn{5}{|l|}{ B.1. Loss due to the quarantine of the area } \\
\hline \multicolumn{5}{|l|}{ B.1.1. Farmers } \\
\hline Percentage of price drop during outbreak & $\mathrm{P}_{\mathrm{ph}}$ & & $90 \%$ & \\
\hline Percentage of sold calves & $\mathrm{P}_{\mathrm{sj}}$ & & $10 \%$ & \\
\hline Loss for the inter-area (interdistrict) traders & $\mathbf{K}_{\mathrm{pd}}$ & $\mathbf{R p}$ & $20,900,000.00$ & per annum \\
\hline \multicolumn{5}{|l|}{ B.1.3. Livestock transportation business owners } \\
\hline Transportation cost for cattle out of Muko muko & $\mathrm{T}_{\mathrm{sl}}$ & $\mathrm{Rp}$ & $200,000.00$ & per head \\
\hline Loss for the transportation business & $\mathrm{K}_{\mathrm{tt}}$ & $\mathbf{R p}$ & $16,720,000.00$ & per annum \\
\hline Total loss due to the quarantine of the area & $\mathrm{K}_{\mathrm{pw}}$ & $\mathbf{R p}$ & $119,700,000.00$ & per annum \\
\hline \multicolumn{5}{|l|}{ B.2. Coccidiosis control costs } \\
\hline B.2.1. Investigation costs & & & & \\
\hline
\end{tabular}




\begin{tabular}{|c|c|c|c|c|}
\hline Number of personnel & $\mathrm{n}_{\mathrm{i}}$ & & 4 & pax \\
\hline Daily rate & $\mathrm{L}_{\mathrm{i}}$ & $\mathrm{Rp}$ & $380,000.00$ & per person / day \\
\hline Accommodation & $\mathrm{B}_{\mathrm{a}}$ & $\mathrm{Rp}$ & $550,000.00$ & per room / day \\
\hline Accommodation unit & $\mathrm{n}_{\mathrm{a}}$ & & 2 & room \\
\hline accommodation days & $\mathrm{H}_{\mathrm{m}}$ & & 3 & day \\
\hline Transportation & $\mathrm{T}_{\mathrm{i}}$ & $\mathrm{Rp}$ & $750,000.00$ & per day \\
\hline Investigation days & $\mathrm{H}_{\mathrm{i}}$ & & 4 & day \\
\hline stationaries & $A_{t}$ & $\mathrm{Rp}$ & $250,000.00$ & per package \\
\hline materials and equipment & $A_{b}$ & $\mathrm{Rp}$ & $500,000.00$ & per package \\
\hline investigation costs & $\mathbf{B}_{\mathbf{i}}$ & $\mathbf{R p}$ & $13,130,000.00$ & per annum \\
\hline \multicolumn{5}{|l|}{ B.2.2. Laboratory costs } \\
\hline Cost of worm detect & $\mathrm{B}_{\mathrm{pcr}}$ & $\mathrm{Rp}$ & $6,000.00$ & per sample \\
\hline Number of feses samples & $\mathrm{n}_{\mathrm{pcr}}$ & & 20 & sample \\
\hline sample submission costs & $\mathrm{B}_{\mathrm{ps}}$ & $\mathrm{Rp}$ & $50,000.00$ & per package \\
\hline Laboratory costs & $\mathrm{B}_{1}$ & $\mathbf{R p}$ & $170,000.00$ & per package \\
\hline \multicolumn{5}{|c|}{ B.2.3 Albendazole + Antibiotic (One type) } \\
\hline Coverage & $\mathrm{C}_{\mathrm{v}}$ & & $100 \%$ & \\
\hline dosages & $\mathrm{n}_{\mathrm{va}}$ & & 760 & dosage \\
\hline Drug price & $\mathrm{H}_{\mathrm{va}}$ & $\mathrm{Rp}$ & $21,800.00$ & per dosage \\
\hline vaccinators & $\mathrm{n}_{\mathrm{vr}}$ & & 10 & pax \\
\hline operational needs & $\mathrm{O}_{\mathrm{vr}}$ & & 10000 & per dosage \\
\hline vaccination costs & $\mathbf{B}_{\mathrm{v}}$ & $\mathbf{R p}$ & $92,568,000.00$ & per annum \\
\hline \multicolumn{5}{|l|}{ B.2.4 Milk Replacement } \\
\hline Milk Replacement & $\mathbf{B}_{\text {in }}$ & $\mathbf{R p}$ & $5,000,000.00$ & per package \\
\hline Coccidiosis control costs & $\mathbf{B}_{\mathrm{pj}}$ & $\mathbf{R p}$ & $110,868,000.00$ & per annum \\
\hline Indirect loss & $\mathrm{K}_{\mathrm{t}}$ & $\mathbf{R p}$ & $230,568,000.00$ & per tahun \\
\hline Coccidiosis total loss & $\mathbf{T}_{\mathrm{KJ}}$ & $\mathbf{R p}$ & $1,600,480,000.00$ & per annum \\
\hline
\end{tabular}

TABLE 4. CALCULATION OF THE SECOND SCENARIO COST AND BENEFIT ANALYSIS (WITH DISCOUNT RATE 5.00\%)

\begin{tabular}{|c|c|c|c|c|c|}
\hline \multirow[b]{2}{*}{ Item } & \multicolumn{4}{|c|}{ Year } & \multirow[t]{2}{*}{ Total } \\
\hline & 0 & 1 & 2 & 3 & \\
\hline Change of Coccidiosis levels & & $0 \%$ & $90 \%$ & $95 \%$ & \\
\hline \multicolumn{6}{|l|}{ Costs } \\
\hline \multicolumn{6}{|l|}{ Capital } \\
\hline \multicolumn{6}{|l|}{ Recurrent costs } \\
\hline Investigation costs & & $13,130,000$ & $13,130,000$ & $13,130,000$ & $39,390,000$ \\
\hline Laboratory costs & & 170,000 & 170,000 & 170,000 & 510,000 \\
\hline Coccidiosis drug + Antibiotic & & $92,568,000$ & $92,568,000$ & $92,568,000$ & $277,704,000$ \\
\hline Milk Replacement & & $5,000,000$ & $5,000,000$ & $5,000,000$ & $15,000,000$ \\
\hline Total costs & 0 & $110,868,000$ & $110,868,000$ & $110,868,000$ & $332,604,000$ \\
\hline \multicolumn{6}{|l|}{ Benefits } \\
\hline Losses of animals and treatments & & 0 & & $1,301,766,000$ & $1,301,766,000$ \\
\hline General economy & & 0 & $107,730,000$ & $113,715,000$ & $221,445,000$ \\
\hline Total benefits & 0 & 0 & $107,730,000$ & $1,415,481,000$ & $1,523,211,000$ \\
\hline $\begin{array}{l}\text { Undiscounted benefits minus } \\
\text { costs }\end{array}$ & $\mathbf{0}$ & $-110,868,000$ & $-3,138,000$ & $1,304,613,000$ & $1,190,607,000$ \\
\hline Discounted costs & $\mathbf{0}$ & $105,588,571$ & $100,560,544$ & $95,771,947$ & $301,921,063$ \\
\hline Discounted benefits & $\mathbf{0}$ & $\mathbf{0}$ & $97,714,286$ & $1,222,745,708$ & $1,320,459,994$ \\
\hline Discounted benefits minus costs & $\mathbf{0}$ & $-105,588,571$ & $-2,846,259$ & $1,126,973,761$ & $1,018,538,931$ \\
\hline NPV & $1,018,538,931$ & & & & \\
\hline BCR & 4.37 & & & & \\
\hline IRR & $241.62 \%$ & & & & \\
\hline
\end{tabular}

TABLE 5 RESUltS OF FECAL AND DRINKING WATER SAMPLE TESTING IN THE CASE OF DEATH OF CALF BALI CALVES IN MUKO MUKo DistRICT IN NOVEMBER 2018 (SUSILO, J 2019)

\begin{tabular}{lcc}
\hline Parasite worm & Positive & Negative \\
\hline Fasciola sp. & $0(0 \%)$ & $20(100 \%)$ \\
Parampistomum sp. & $1(5 \%)$ & $19(95 \%)$ \\
Ascaris & $1(5 \%)$ & $19(95 \%)$ \\
Eimmeria & $8(40 \%)$ & $12(60 \%)$ \\
Trichostrongylus & $2(10 \%)$ & $18(90 \%)$ \\
Strongyloides & $1(5 \%)$ & $19(95 \%)$ \\
\hline Water source & & \\
\hline Swamp & E.coli $3.6 \times 10^{\circ} \mathrm{MPN} / \mathrm{ml}$ & Coliform $150 \mathrm{MPN} / \mathrm{ml}$ \\
Well & E.coli $2.9 \times 10^{\circ} \mathrm{MPN} / \mathrm{ml}$ & Coliform $100 \mathrm{MPN} / \mathrm{ml}$ \\
\hline
\end{tabular}

